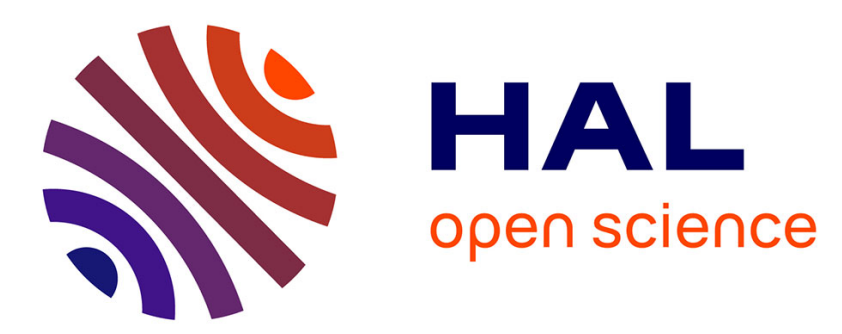

\title{
Unravelling Platinum-Zirconia Interfacial Sites Using CO Adsorption
}

Frederic C Meunier, Raphael Kdhir, Natalia Potrzebowska, N. Perret, Michèle Besson

\section{- To cite this version:}

Frederic C Meunier, Raphael Kdhir, Natalia Potrzebowska, N. Perret, Michèle Besson. Unravelling Platinum-Zirconia Interfacial Sites Using CO Adsorption. Inorganic Chemistry, 2019, 58 (12), pp.80218029. 10.1021/acs.inorgchem.9b00774 . hal-02174237

\section{HAL Id: hal-02174237 https://hal.science/hal-02174237}

Submitted on 11 Aug 2021

HAL is a multi-disciplinary open access archive for the deposit and dissemination of scientific research documents, whether they are published or not. The documents may come from teaching and research institutions in France or abroad, or from public or private research centers.
L'archive ouverte pluridisciplinaire HAL, est destinée au dépôt et à la diffusion de documents scientifiques de niveau recherche, publiés ou non, émanant des établissements d'enseignement et de recherche français ou étrangers, des laboratoires publics ou privés.

\section{(ㄷ)(1)}

Distributed under a Creative Commons Attribution| 4.0 International License 


\section{Unravelling Platinum-Zirconia Interfacial Sites}

\section{2 using $\mathrm{CO}$ Adsorption.}

3 Frederic C. Meunier*, Raphael Kdhir, Natalia Potrzebowska, Noémie Perret, Michèle Besson,

4 Univ Lyon, Université Claude Bernard Lyon 1, CNRS, IRCELYON, 2 Av. Albert Einstein, 69626

5 Villeurbanne (France).

6 KEYWORDS: CO adsorption; platinum; FT-IR; DRIFTS; multi-bonded carbonyl.

8 ABSTRACT: Understanding platinum speciation on catalysts is crucial for the design of atom-

9 efficient materials and optimized formulations. The adsorption of $\mathrm{CO}$ as probe molecule is

10 widely used to reveal Pt dispersion and structures, yet the assignment of IR bands is not

11 straightforward, hindering the determination of the nature of the surface sites or ensemble

12 involved. CO adsorption was studied here over a zirconia-supported Pt catalyst. Specific sites at

13 the interface between $\mathrm{Pt}$ and the support were highlighted giving rise to an unusual band around

$141660 \mathrm{~cm}^{-1}$ that could be confidently assigned to a $\mathrm{Pt}_{2}-\mathrm{CO}$ bridging carbonyl interacting head-on

15 with a support surface hydroxyl. This adduct was yet unstable in the present conditions and was

16 converted into linear and bridged carbonyl only bound to Pt. Such sites are potentially important

17 for bifunctional reactions requiring both metal and acid/base properties, particularly those

18 occurring at the metal - support perimeter. Such adducts have probably been mistaken for 
1 carbonate-type species in many past contributions and could potentially represent crucial

2 reaction intermediates for $\mathrm{CO}$ oxidation and the water-gas shift reaction.

4 1. Introduction

5

6

11 in the adsorbed state. Yet, the assignment of IR bands is not always straightforward, hindering

12 the determination of the nature of the surface sites present.

13 The difficulty in interpreting IR spectra related to $\mathrm{CO}$ adsorption on platinum-based surfaces

14 and catalysts has long been discussed. ${ }^{4}$ The stretching frequency $v(\mathrm{CO})$ is affected, among

15 others, by the nature (e.g. coordination number, oxidation state) of the Pt sites present, CO

16 adsorption modes and lateral interactions between adsorbed $\mathrm{CO}$ (so called "dipole-dipole 17 coupling”).

18 Lateral interactions imply band intensity transfer that can make spectral interpretation difficult, 19 even at low surface coverage if island formation takes place. ${ }^{5,6}$ Lateral interactions were shown 20 to be markedly decreased in the case of intermetallic Pt-Sn nanoalloys, in which Pt atoms are 21 spatially separated by Sn atoms. ${ }^{7}$ The wavenumber of $v(\mathrm{CO})$ free of dipole-dipole interaction is 22 otherwise determined by using isotopically labelled mixtures of ${ }^{12} \mathrm{CO}$ and ${ }^{13} \mathrm{CO}$, which exhibit a 23 wavenumber ratio of $v\left({ }^{12} \mathrm{CO}\right) / v\left({ }^{13} \mathrm{CO}\right)=1.023$. The ca. $50 \mathrm{~cm}^{-1}$ wavenumber difference is 
1 sufficient to decouple these electrodynamic vibrators and obtain the so-called "singleton" value

2 for the diluted isotopomer.4

3 The coordination number (C.N.) of the Pt atoms affects dramatically the wavenumber of the

4 stretching vibration of the adsorbed CO. Kappers and van der Maas ${ }^{8}$ reported a linear correlation

5 between the wavenumber of linearly adsorbed $\mathrm{CO}$ and $\mathrm{Pt}$ coordination number, ranging from

$61996 \mathrm{~cm}^{-1}$ (C.N. = 3, Pt adatom) up to $2096 \mathrm{~cm}^{-1}$ (C.N. = 9, Pt in (111) plane). These

7 assignments were based on a few assumptions, including a cubo-octahedral shape for the Pt

8 crystals (from which the proportion of sites with a given coordination can be determined) ${ }^{9}$ and a

9 complex band decomposition based on second derivatives.

10 The oxidation state of Pt strongly affects the position of the $\mathrm{CO}$ band. While $\mathrm{CO}$ adsorbed on

11 metallic sites typically exhibit wavenumbers lower than $2096 \mathrm{~cm}^{-1}$, Hadjiivanov and co-workers

12 showed that (single atom) cationic Pt in zeolite-based materials absorb at much higher

13 wavenumbers. ${ }^{10,11,12} \mathrm{Pt}^{3+}$ cations were shown to form $\mathrm{Pt}^{3+}(\mathrm{CO})_{2}$ dicarbonyls leading to doublets,

14 with high and low wavenumber bands ranging from 2211 to $2195 \mathrm{~cm}^{-1}$ and from 2175 to 2155

$15 \mathrm{~cm}^{-1}$, respectively. In the case of $\mathrm{Pt}^{2+}$, both mono and dicarbonyls were observed. $\mathrm{Pt}^{2+}-\mathrm{CO}$

16 species were absorbing typically over the range $2155-2141 \mathrm{~cm}^{-1}$, while the $\mathrm{Pt}^{2+}(\mathrm{CO})_{2}$ dicarbonyls

17 exhibiting a doublet at 2165 and $2150 \mathrm{~cm}^{-1}$. In the case of $\mathrm{Pt}^{+}$, monocarbonyl $\mathrm{Pt}^{+}-\mathrm{CO}$ (ca. 2112

$\left.18 \mathrm{~cm}^{-1}\right)$, dicarbonyls $\mathrm{Pt}^{+}(\mathrm{CO})_{2}\left(2135-2120\right.$ and 2101-2091 $\left.\mathrm{cm}^{-1}\right)$ and tricarbonyls $\mathrm{Pt}^{+}(\mathrm{CO})_{3}(2162$,

192150 and $2110 \mathrm{~cm}^{-1}$ ) were proposed. These authors also proposed that supported $\mathrm{Pt}^{4+}$ ions are

20 coordinatively saturated and not able to form carbonyls after $\mathrm{CO}$ adsorption.

21 CO adsorption on single atom Pt species has also been reported on other traditional non-

22 zeolitic oxide supports. Single atom Pt species, presumably $\mathrm{Pt}^{2+}$, supported on ceria lead to bands

23 around $2090 \mathrm{~cm}^{-1} \cdot{ }^{13,14}$ Stair and co-workers assigned bands around $2105 \pm 10 \mathrm{~cm}^{-1}$ to positively 
1 charged single atom Pt present on silica, alumina and titania. ${ }^{1}$ The band was located around 2090

$2 \pm 10 \mathrm{~cm}^{-1}$ in the case of zirconia. The $\mathrm{CO}$ adsorbed on single atom species could be

3 discriminated from those adsorbed on Pt nanoparticles by the fact that the latter were removed

4 through oxidation by $\mathrm{O}_{2}$ even at room temperature, while the $\mathrm{CO}$ adsorbed on single atoms were 5 unreactive at low temperatures.

6 The mode of binding of $\mathrm{CO}$ affects markedly $v(\mathrm{CO})$. Surface science data collected by

7 Hayden and Bradshaw on $\operatorname{Pt}(111)$ surfaces between at $85-300 \mathrm{~K}$ reported on-top (linearly 8 adsorbed) $\mathrm{CO}$ at $2110 \mathrm{~cm}^{-1}$, two-fold bridge $\mathrm{CO}$ at 1842 and three-fold bridge $\mathrm{CO}$ at $1822 \mathrm{~cm}^{-1} .{ }^{15}$

9 Note that the $2110 \mathrm{~cm}^{-1}$ value for linear species absorption is significantly higher than the value 10 expected for $\mathrm{CO}$ adsorbed on metallic Pt atom with a C.N. $=9$, which is $2096 \mathrm{~cm}^{-1}$ as proposed 11 by the model of Kappers and van der Maas.8 This difference is probably due to the occurrence of 12 dipole-dipole effects in the case of the data reported on $\operatorname{Pt}(111)$ leading to a large increase of the 13 wavenumber value.

14 Heterobridging $\mathrm{CO}$ species have been proposed by a number of teams. $\mathrm{CO}$ bridged between $\mathrm{Pt}$ 15 and sites of the alumina support that adsorbed at $1756 \mathrm{~cm}^{-1}$ were proposed by Ferri et al. ${ }^{16}$ Dilara 16 and Vohs assigned bands located at 1680 and $1570 \mathrm{~cm}^{-1}$ to a head-and-tail $\mathrm{CO}$ adduct formed 17 between $\mathrm{Pt}$ and a $\mathrm{Zr}^{4+}$ cation, while linear and bridged $\mathrm{CO}$ solely adsorbed on $\mathrm{Pt}$ absorbed at 182065 and $1815 \mathrm{~cm}^{-1}$, respectively (Fig. 1.A). ${ }^{17}$ Carbonyl coordination complexes of various 19 metals exhibit bands at low wavenumbers, such as $1662 \mathrm{~cm}^{-1}$ assigned to a "semitriple bridging" 20 carbonyl in $\mathrm{PtCo}_{2}(\mathrm{CO})_{5}\left(\mu \mathrm{Ph}_{2} \mathrm{P}-\mathrm{CH}_{2}-\mathrm{PPh}_{2}\right)$ (Fig. 1.B) ${ }^{18}$ The formation of adducts through the 21 oxygen atom of $\mathrm{CO}$ interacting with Lewis centre can decrease $v(\mathrm{CO})$ by as much as $232 \mathrm{~cm}^{-1}$, as 22 in the case of $\mathrm{Co}_{2}(\mathrm{CO})_{8}$ and its adduct with $\mathrm{AlBr}_{3}$ (Fig. 1.C). ${ }^{19}$ The wavenumber of the bridging 
1 carbonyl forming the adduct was $1600 \mathrm{~cm}^{-1}$, as compared to $1832 \mathrm{~cm}^{-1}$ for the parent bridged 2 species.

(A)

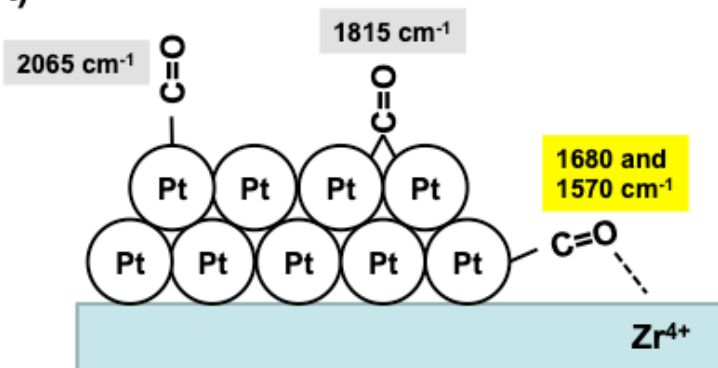

(B)

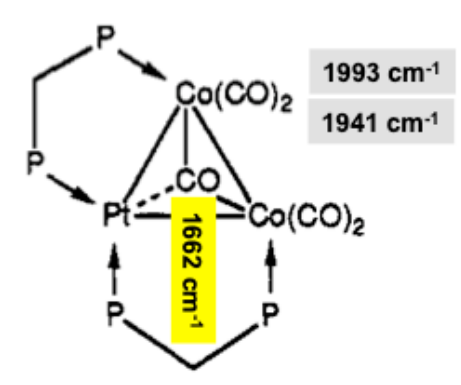

(C)

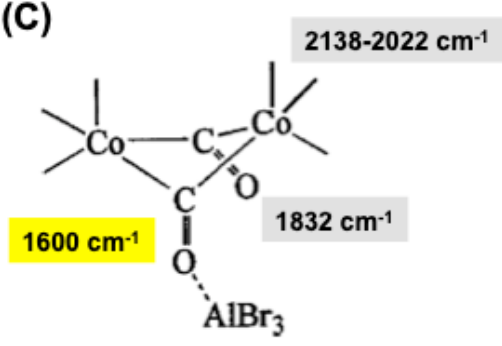

4

9 The formation of carbonates and hydrogenocarbonates should always be considered when

10 adsorbing $\mathrm{CO}$ on catalyst surfaces because of the presence of residual traces of $\mathrm{CO}_{2}$ or its

11 formation in situ though various reactions that are easily catalyzed by metals, e.g. Boudouard (2

$\left.12 \mathrm{CO} \rightarrow \mathrm{C}+\mathrm{CO}_{2}\right)$, water-gas shift $\left(\mathrm{CO}+\mathrm{H}_{2} \mathrm{O} \rightarrow \mathrm{H}_{2}+\mathrm{CO}_{2}\right)$ and oxidation with oxygen supplied

13 by residual dioxygen or the catalyst $\left(\mathrm{CO}+\mathrm{O} \rightarrow \mathrm{CO}_{2}\right)$. Surface carbonates typically exhibit two

14 bands between 1700 and $1100 \mathrm{~cm}^{-1}$, resulting from the splitting of the $v_{3}$ band (asymmetric $\mathrm{CO}_{3}$

15 stretching) at $1415 \mathrm{~cm}^{-1}$ of the free carbonate ion, which exhibits $\mathrm{D}_{3 \mathrm{~h}}$ symmetry. ${ }^{20}$ The 
1 wavenumber difference between the two bands $\left(\Delta v_{3}\right)$ depends on the carbonate coordination

2 mode, ${ }^{21}$ but also on the charge and radius of the cation it is adsorbed on. ${ }^{22}$ Monodentate 3 carbonate can exhibit $\triangle v_{3}$ as low as $60 \mathrm{~cm}^{-1}$ (e.g. 1460 and $1400 \mathrm{~cm}^{-1}$ on $\alpha-\mathrm{Fe}_{2} \mathrm{O}_{3}$ ), ${ }^{23}$ while

4 bidendate and bridged carbonate can present $\triangle v_{3}$ above $300 \mathrm{~cm}^{-1}$ (e.g. 1610 and $1290 \mathrm{~cm}^{-1}$ on $\alpha-$ $\left.5 \mathrm{Fe}_{2} \mathrm{O}_{3}\right)^{23}$.

6 Newton et al. ${ }^{24}$ assigned the signal of a single band located at $1690-1670 \mathrm{~cm}^{-1}$ observed over 7 alumina-supported Pt to a Pt carbonate species. This band was shown to be a crucial reaction 8 intermediate in the formation of $\mathrm{CO}_{2}$ during $\mathrm{CO}+\mathrm{O}_{2}$ reaction using a combination of operando 9 DRIFTS and mass spectrometry data. The assignment of this band to a carbonate may yet be 10 questioned in view of the aforementioned discussion.

11 Hydrogenocarbonates are typically formed from the reactive adsorption of $\mathrm{CO}_{2}$ on surface 12 hydroxyl groups ${ }^{25}$ and the characteristics IR bands at the surface of $\mathrm{ZrO}_{2}$ are located at 1625 $13\left(v_{\mathrm{a}}\left(\mathrm{CO}_{3}\right)\right), 1425\left(v_{\mathrm{s}}\left(\mathrm{CO}_{3}\right)\right)$ and $1222(\delta(\mathrm{OH})) \mathrm{cm}^{-1} \cdot{ }^{26}$ Carboxylates (i.e. $\mathrm{CO}_{2}$ adsorbed on a metal 14 centre) also typically present a pair of bands between 1700 and $1200 \mathrm{~cm}^{-1} .22$

15 We are revisiting here the speciation of Pt supported over a zirconia support. $\mathrm{Pt} / \mathrm{ZrO}$ and $16 \mathrm{Pt} / \mathrm{sulfated}-\mathrm{ZrO}_{2}$ catalysts have raised a lot of interest for a wide range of important reactions 17 such as water-gas shift ${ }^{27}$, methane dry reforming ${ }^{28}$, aqueous phase selective oxidation ${ }^{29}$ and 18 reforming ${ }^{30}$ of biomass-derived compounds, room temperature oxidation of formaldehyde ${ }^{31}$ and $19 \mathrm{CO}^{32}$, electrooxidation of alcohols $\mathrm{s}^{33,34}$ and alkane isomerization ${ }^{35,36}$. The speciation of Pt over 20 zirconia using $\mathrm{CO}$ as molecular probe was investigated and revealed a variety of sites ranging 21 from isolated Pt atoms to large Pt particles. Specific sites at the interface between Pt and the $22 \mathrm{ZrO}_{2}$ support were also highlighted. These interfacial sites exhibited yet a limited stability in the 23 present conditions. Such sites are potentially important for bifunctional reactions requiring both 
1 metal and acid/base properties, particularly those thought to be occurring at the metal - support

2 perimeter.

4 2. Experimental Section

5

6 The zirconia supplied by MEL Chemicals (XZO 632-18) exhibited a surface area of $136 \mathrm{~m}^{2} \mathrm{~g}^{-}$

7 . The Pt precursor hexachloroplatinic acid $\left(\mathrm{H}_{2} \mathrm{PtCl}_{6}, 6 \mathrm{H}_{2} \mathrm{O} 99.9 \%\right)$ was bought from Alfa Aesar,

$8 \mathrm{NaBH}_{4}$ was purchased from Acros Organics. The zirconia-supported Pt was prepared by wet

9 impregnation using $\mathrm{NaBH}_{4}$ as the reducing agent. The support (ca. $\left.5 \mathrm{~g}\right)$ and deionized water $(250$

$10 \mathrm{~mL}$ ) were introduced in a $1 \mathrm{~L}$ round-bottom flask. The appropriate volume of an aqueous

11 solution of $\mathrm{H}_{2} \mathrm{PtCl}_{6}$ (containing $14.4 \mathrm{gPt}_{\mathrm{Pt}} \mathrm{L}^{-1}$ ) was added and the impregnation took place under

12 moderate stirring in an ultrasound bath $(37 \mathrm{kHz})$ for $3 \mathrm{~h}$. After cooling to ca. $10^{\circ} \mathrm{C}$ with an ice

13 bath, a freshly prepared $\mathrm{NaBH}_{4}$ solution $(0.73 \mathrm{~g}$ in $50 \mathrm{~mL}$ deionized water $)$ was slowly added

14 under vigorous stirring. The suspension immediately turned to black and was stirred for an

15 additional $2 \mathrm{~h}$. The solid was filtered, washed with water, and dried at $60^{\circ} \mathrm{C}$ under nitrogen

16 overnight. The Pt loading was measured by Inductively Coupled Plasma-Optical Emission

17 Spectrometry (ICP-OES, Jobin Yvon Activa) after mineralization of the solid. The Pt loading

18 measured was $2.2 \mathrm{wt} \%$.

19 Powder X-ray diffraction patterns were recorded on a Bruker D8 Advance A25 diffractometer 20 using $\mathrm{Cu} \mathrm{K \alpha}$ radiation $(\lambda=0.1541 \mathrm{~nm})$ in the range between $2 \theta=20-60^{\circ}$ at a step of $0.02^{\circ} \mathrm{s}^{-1}$.

21 The crystalline phases were identified by reference to the JCPDS files. 
The TEM images were obtained using a JEOL 2010 microscope with LaB6 source operated at

$2 \quad 200 \mathrm{kV}$. The sample was suspended in EtOH solution and a drop of the sonicated suspension was

3 deposited onto carbon-coated $\mathrm{Cu}$ grid and solvent was evaporated.

$4 \quad$ High purity gases He (99.999\%) and CO (99.9\%) from Air Liquid were used. The gases were

5 further purified using a liquid nitrogen trap located just before the DRIFTS cell to remove traces

6 of water, $\mathrm{CO}_{2}$ and hydrocarbons.

7 DRIFTS experiments were performed at $50^{\circ} \mathrm{C}$ with a modified high temperature DRIFT cell

8 (from Spectra-Tech) fitted with $\mathrm{KBr}$ windows, using a DRIFT-II assembly. A description and

9 properties of the cell can be found in earlier references. ${ }^{37,38}$ The spectrophotometer used was a

10 Nicolet 6700 (ThermoFischer Scientific) fitted with a liquid-N $\mathrm{N}_{2}$ cooled MCT detector. The

11 DRIFT spectra were recorded at a resolution of $4 \mathrm{~cm}^{-1}$ and 32 scans were averaged. The

12 DRIFTS spectra are reported as $\log (1 / \mathrm{R})$, where $\mathrm{R}$ is the sample reflectance. This pseudo-

13 absorbance gives a better linear representation of the band intensity against surface coverage

14 than that given by the Kubelka-Munk function for strongly absorbing media such as those based

15 on metals supported on oxides. ${ }^{39}$ The contribution of gas-phase $\mathrm{CO}$ was subtracted using a

$16 \mathrm{CO}(\mathrm{g})$ spectrum collected under the same experimental condition over $\mathrm{KBr}$ powder.

18 3. Results

$19 \quad$ 3.1. Sample characterization

21 The XRD patterns of the zirconia support and $\mathrm{Pt} / \mathrm{ZrO}_{2}$ solid are shown in Fig. 1. The support

22 sample showed intense peaks indexed to the monoclinic phase (JCPDS 00-037-1484). The

23 pattern also showed peaks associated with the tetragonal phase (JCPDS 01-80-0965). The ratio 
1 of $m-\mathrm{ZrO}_{2} / \mathrm{t}-\mathrm{ZrO}_{2}$ is of $90 \% / 10 \%$, as determined by Rietveld refinement, using the Topas 5

2 software. The XRD pattern of the material containing $2.2 \mathrm{wt} . \% \mathrm{Pt}$ was essentially identical, 3 excepted for a weak and wide peak at ca. $2 \theta=39.9^{\circ}$ associated with the (111) plane of cubic Pt 4 (Fig. 1, inset in the region between 37 and $43^{\circ}$ ).

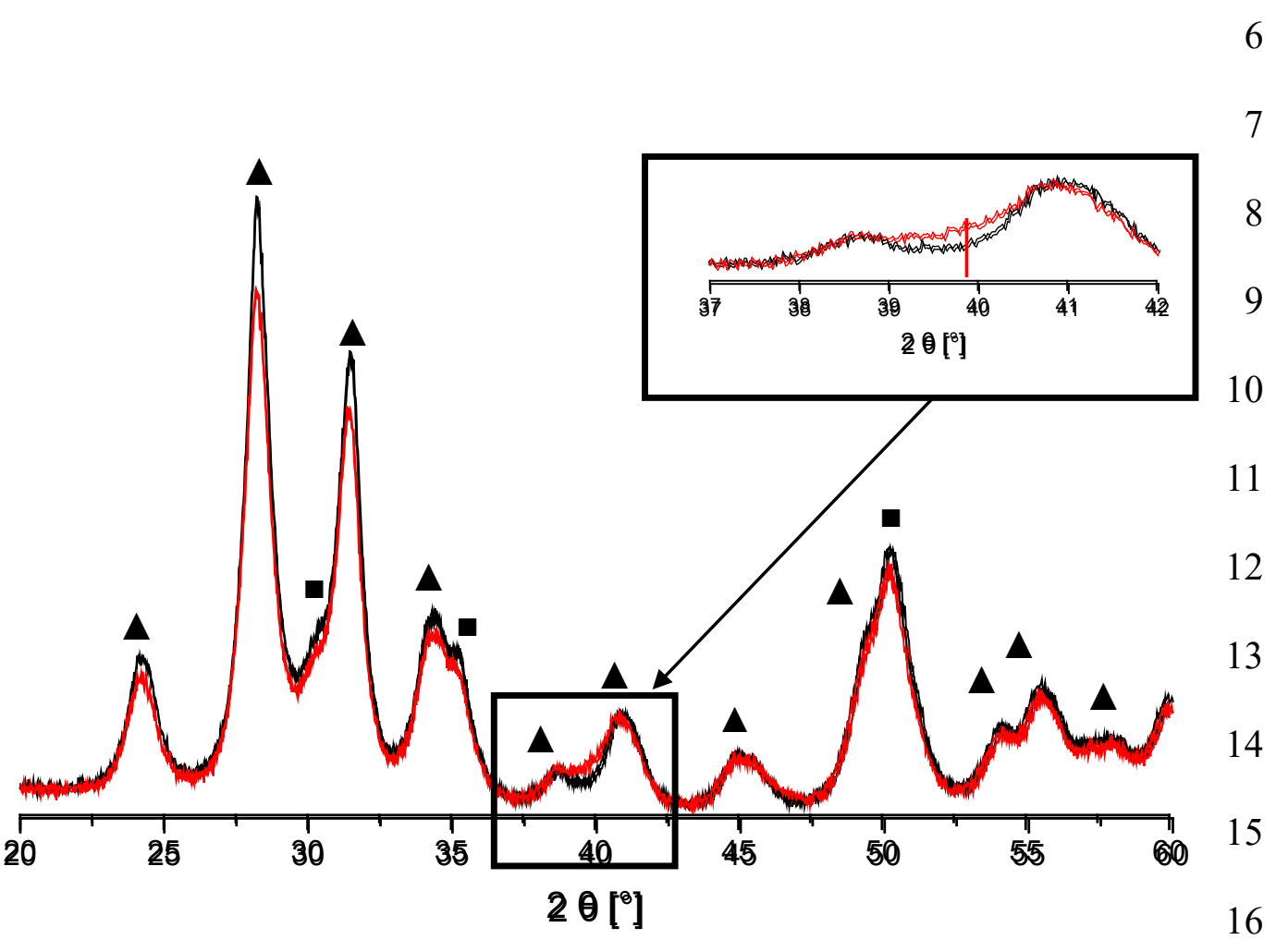

17

19 Figure 1. $\mathrm{XRD}$ patterns of bare $\mathrm{ZrO}_{2}$ and $\mathrm{Pt} / \mathrm{ZrO}_{2}$. The peaks corresponded to: monoclinic $20 \quad \mathrm{ZrO}_{2}$ JCPDS 00-037-1484 (ム), tetragonal $\mathrm{ZrO}_{2}$ JCPDS 01-80-0965 (•) and Pt JCPDS 00-004210802. 

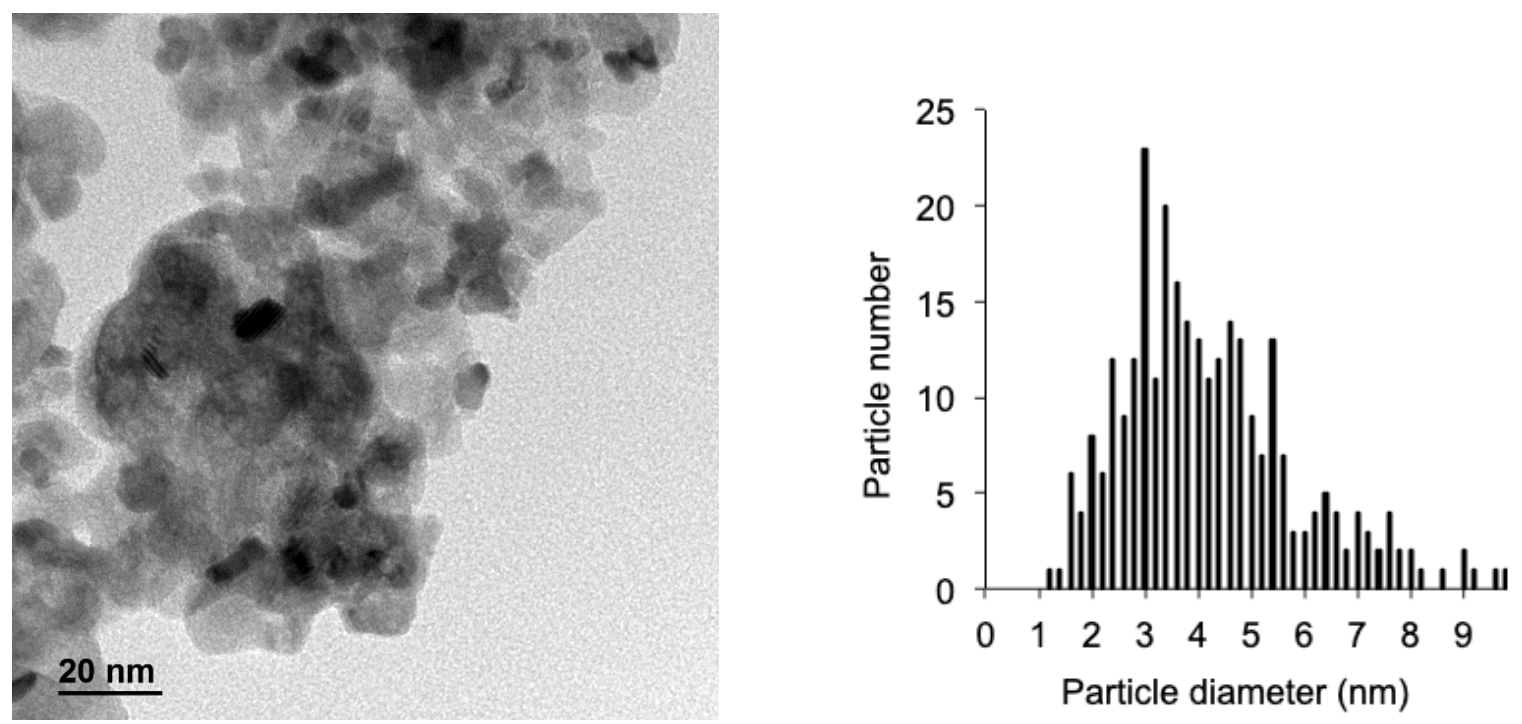

2 Figure 2. TEM picture of the $\mathrm{Pt} / \mathrm{ZrO}_{2}$ catalyst and the corresponding distribution of $\mathrm{Pt}$ particle 3 sizes.

4

5 The Pt particle size distribution measured by TEM counting about 200 particles is given in Fig.

6 2. Most Pt particles were comprised between 2 and $6 \mathrm{~nm}$ in diameter, with a mean particle size of

$7 \quad 4.5 \mathrm{~nm}$ leading to Pt dispersion of about $22 \%$.

8 The DRIFTS spectra of the $\mathrm{ZrO}_{2}$ support and $\mathrm{Pt} / \mathrm{ZrO}_{2}$ heated for 30 min in $\mathrm{He}$ at $50^{\circ} \mathrm{C}$ were

9 similar in nature (Fig. 3). Though the commercial zirconia used was not sulfated, evident bands

10 centered around $1356 \mathrm{~cm}^{-1}$ were observed and corresponded to $\mathrm{ZrO}_{2}$-bound sulfate species. ${ }^{40,41}$

11 Bands in the $3800-2500 \mathrm{~cm}^{-1}$ region corresponded to various free and H-bonded hydroxyl

12 groups. The bands at 1625 and $1556 \mathrm{~cm}^{-1}$ can be assigned to the overlap of various bands 13 associated with adsorbed water and carbonate species.

14 


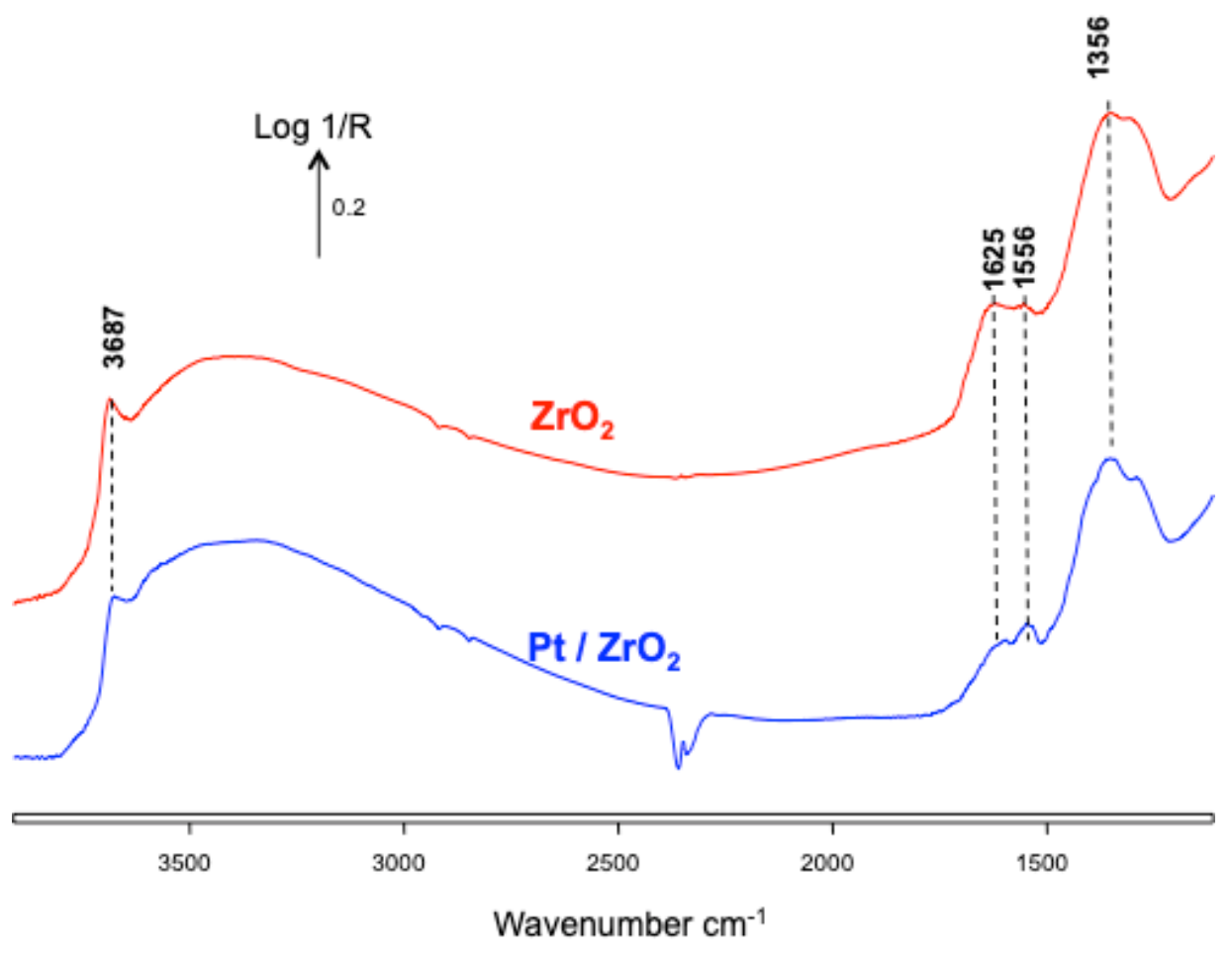

2 Figure 3. DRIFTS spectra of $\mathrm{ZrO}_{2}$ and $\mathrm{Pt} / \mathrm{ZrO}_{2}$ recorded at $50^{\circ} \mathrm{C}$ after $1 \mathrm{~h}$ in $\mathrm{He}$. $\mathrm{KBr}$ signal

3 was used as background.

\subsection{Water adsorption on $\mathrm{ZrO}_{2}$}

The effect of the addition of water was investigated over the $\mathrm{ZrO}_{2}$ support. Water was

7 added by passing the He stream into a water-filled saturator kept at $0^{\circ} \mathrm{C}$. The presence of water

8 resulted in the formation/increase of several IR bands as well as the displacement of bands

9 previously present (Fig. 4). The $1640 \mathrm{~cm}^{-1}$ band corresponded to the bending mode of adsorbed

10 water. The large band with a maximum at $3432 \mathrm{~cm}^{-1}$ was due to the stretching modes of adsorbed

11 water and surface hydroxyls, both being hydrogen-bonded, also resulting in the displacement of

12 hydroxyl groups previously present at 3763 and $3680 \mathrm{~cm}^{-1}$ towards lower wavenumbers. The

$132071 \mathrm{~cm}^{-1}$ is a band associated with surface hydroxyls and water, so-called Evan's windows, due

14 to Fermi resonance between hydroxyl vibration modes. The negative bands at 1385 and $1280 \mathrm{~cm}^{-}$ 
$1{ }^{1}$ were due to the perturbation of sulfate groups by water. All these changes were gradually

2 reversed once water was removed from the feed (Fig. 4.e).

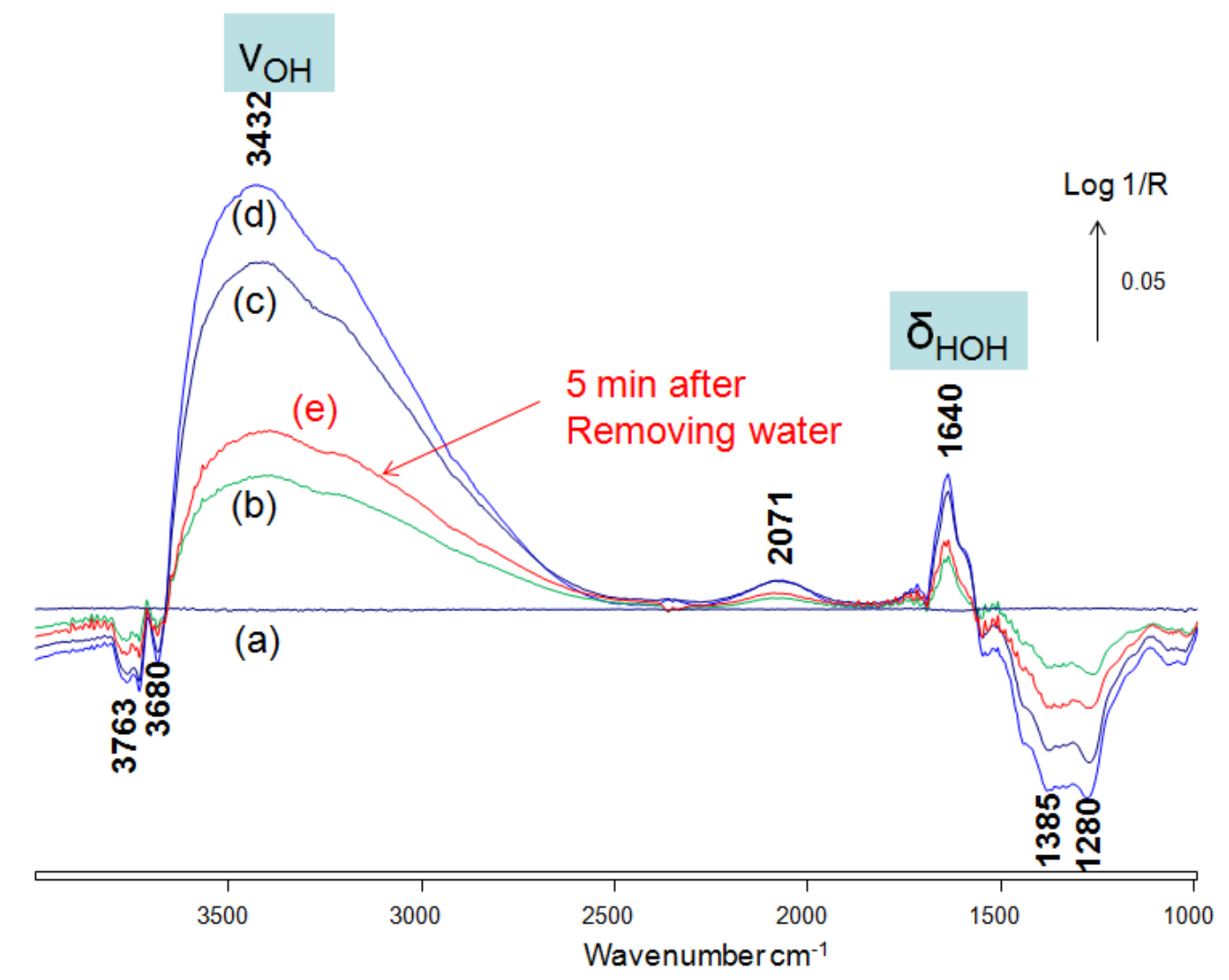

4 Figure 4. Examples of DRIFTS spectra of the support $\mathrm{ZrO}_{2}$ at $50^{\circ} \mathrm{C}$ under $30 \mathrm{~mL} \mathrm{~min}^{-1}$ of $\mathrm{He}$

5 recorded (a-d) over a 10 min period following the introduction of $0.6 \mathrm{kPa}$ of water and (e) $5 \mathrm{~min}$

6 after removing water. The DRIFTS signal collected over the sample dried for 30 min at $50^{\circ} \mathrm{C}$

7 under He was used as background.

8

9 The signal of the hydroxyl stretching bands formed during water adsorption exhibited a linear

10 correlation with that of water bending mode (Fig. 5). The line offset was likely due to the

11 dissociative adsorption of water over $\mathrm{Zr}-\mathrm{O}-\mathrm{Zr}$ oxo-bridges and sulfone $\mathrm{S}=\mathrm{O}$ groups, which led to

12 the formation of new hydroxyl groups without any corresponding signal from water bending 
1 mode. The slope of the line indicate that the molar absorption coefficient of the $-\mathrm{OH}$ stretching

2 band was ca. 20-fold higher than that of water bending mode.

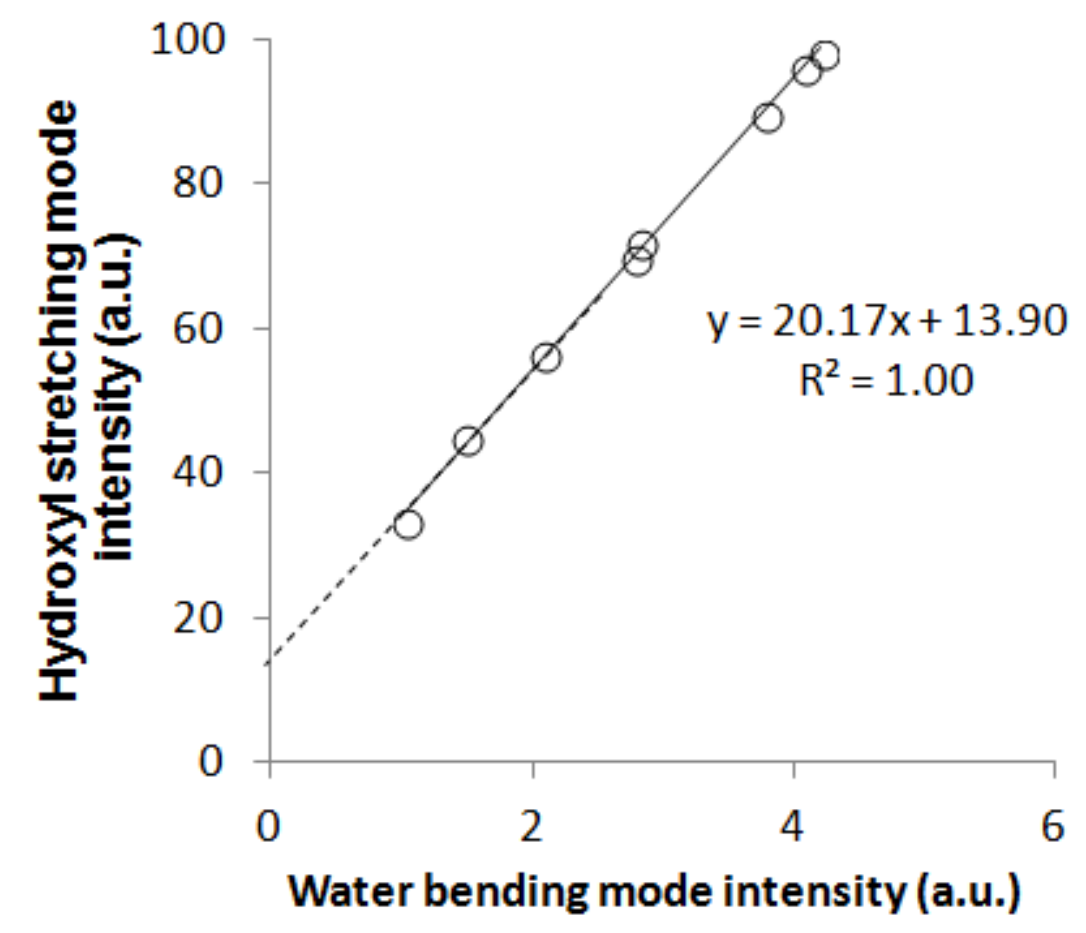

4

5 Figure 5. Evolution of the intensity of the DRIFTS signal of the hydroxyl stretching bands

6 (integrated over 3647-2500 $\mathrm{cm}^{-1}$ ) versus that of water bending mode (integrated over 1690-1576

$7 \mathrm{~cm}^{-1}$ ) during water uptake at $50^{\circ} \mathrm{C}$.

\section{$9 \quad$ 3.3. CO adsorption}

10 The samples were investigated without applying any in situ pre-treatment apart from

11 stabilizing the sample in $\mathrm{He}$ for $1 \mathrm{~h}$ at $50^{\circ} \mathrm{C}$. $\mathrm{CO}$ adsorption was then monitored at $50^{\circ} \mathrm{C}$. No

12 band formation could be detected in the case of the bare support (data not shown). In contrast, 13 many bands were formed on the $\mathrm{Pt} / \mathrm{ZrO}_{2}$. 


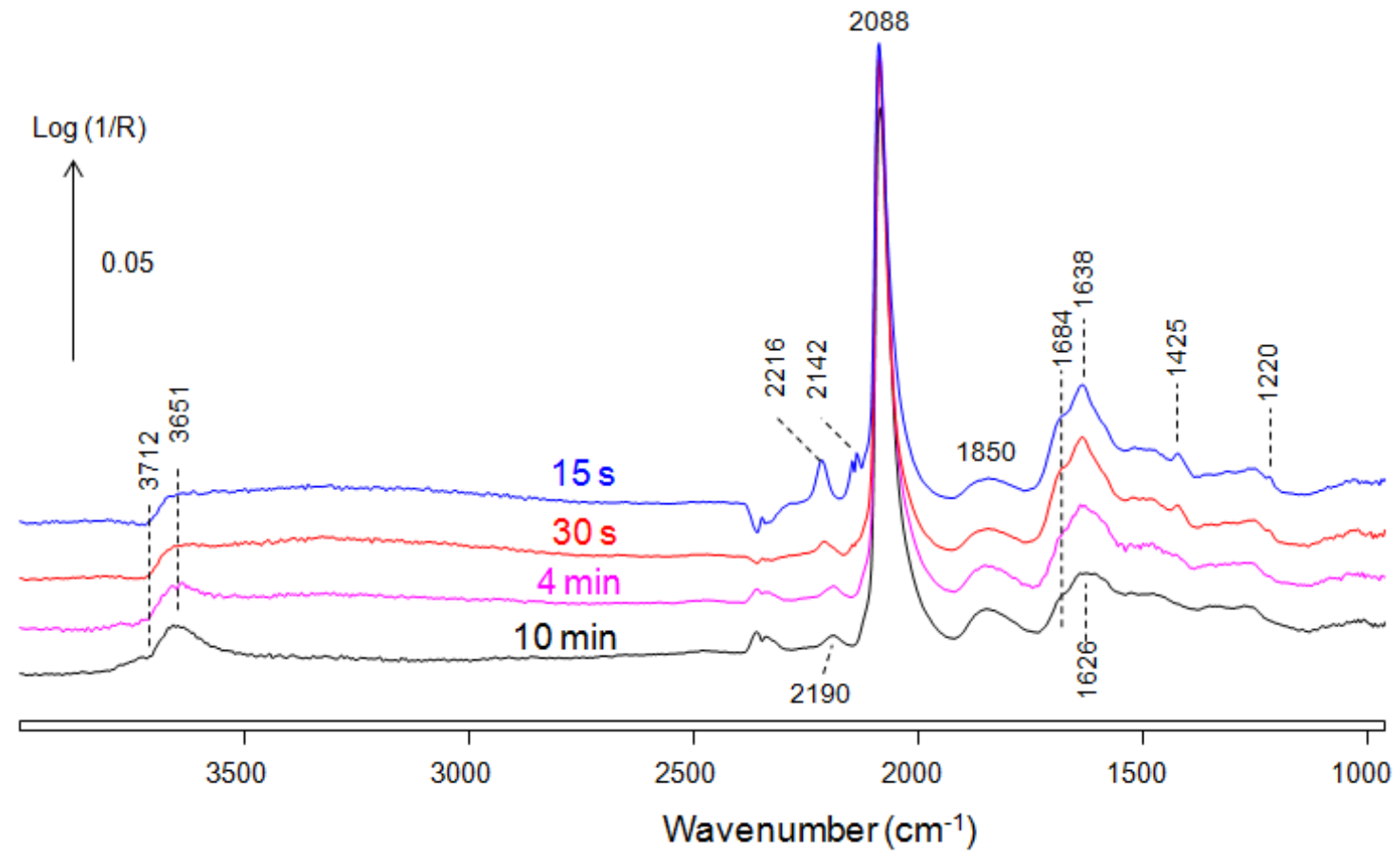

2 Figure 6. DRIFTS spectra collected over the $\mathrm{Pt} / \mathrm{ZrO}_{2}$ at $50^{\circ} \mathrm{C}$ under $3 \% \mathrm{CO} / \mathrm{He}$ at various 3 times following $\mathrm{CO}$ introduction. The sample spectrum collected under $\mathrm{He}$ before $\mathrm{CO}$ 4 introduction was used as background. The gas-phase spectrum of CO was subtracted.

6 The main band observed over the $\mathrm{Pt} / \mathrm{ZrO}_{2}$ following $\mathrm{CO}$ introduction was located at $2088 \mathrm{~cm}^{-1}$

7 (Fig. 6 and Table 1) and corresponded to $\mathrm{CO}$ linearly adsorbed on Pt atoms with high 8 coordination numbers as present in the terraces of the nanoparticles (Fig. 2). The asymmetric 9 shape of the band and the tail towards lower wavenumbers down to $1970 \mathrm{~cm}^{-1}$ was associated 10 with CO linearly adsorbed on sites with lower coordination numbers and smaller nanoparticles. 11 The band located at $1850 \mathrm{~cm}^{-1}$ is assigned to bridged $\mathrm{CO}$ adsorbed on metallic Pt.

12 A doublet was initially visible at 2216 and $2142 \mathrm{~cm}^{-1}$ that is likely assigned to geminal $\mathrm{CO}$ 13 adsorbed on oxidized Pt sites (Fig. 6 and Table 1). The intensity of this doublet rapidly decreased 14 within the first $30 \mathrm{~s}$ of exposure to $\mathrm{CO}$, suggesting that some of the oxidized Pt was getting 15 reduced in the presence of $\mathrm{CO}$, thereby releasing some $\mathrm{CO}_{2}$. The $\mathrm{CO}_{2}$ evolved was responsible 
1 for the formation of minor bands due to hydrogenocarbonates at ca. $1638+1425+1220 \mathrm{~cm}^{-1}$,

2 which had then vanished after $4 \mathrm{~min}$. A weak band at $2190 \mathrm{~cm}^{-1}$ remained, likely due to $\mathrm{CO}$

3 linearly adsorbed on some still oxidized Pt.

4

5 Table 1. IR band assignment related to ${ }^{12} \mathrm{CO}$ (and ${ }^{13} \mathrm{CO}$, in brackets) adsorption. " $\mathrm{L}$ " refers to 6 linearly adsorbed $\mathrm{CO}$ and "B" to bridged $\mathrm{CO}$ between two Pt atoms. The wavenumber ratio 7 between gas-phase ${ }^{12} \mathrm{CO}$ and ${ }^{13} \mathrm{CO}$ is 1.023 .

\begin{tabular}{|l|c|c|c|}
\hline Wavenumber $\left(\mathrm{cm}^{-1}\right)$ & $\begin{array}{r}{ }^{12} \mathrm{CO} /{ }^{13} \mathrm{CO} \\
\text { wavenumber ratio }\end{array}$ & References \\
\hline $2216+2142$ & n.d. & $\mathrm{Pt}^{3+}-(\mathrm{CO})_{2}$ & $10,11,12$ \\
\hline $2190(2135)$ & 1.026 & $\mathrm{~L}-\mathrm{CO}$ on $\mathrm{Pt}^{3+}$ & $10,11,12$ \\
\hline $2088(2032)$ & 1.028 & $\mathrm{~L}-\mathrm{CO}$ on $\mathrm{Pt}^{\circ}$ & 4,8 \\
\hline $1850(1794)$ & 1.031 & $\mathrm{~B}-\mathrm{CO}$ on $\mathrm{Pt}^{\circ}$ & 15 \\
\hline 1684 & n.d. & B-CO $\cdots \cdot \mathrm{HO}^{\circ}$ & This work \\
\hline $1626(1586)$ & 1.025 & B-CO $\cdots \cdot \mathrm{HO}-$ & This work \\
\hline $1700-1200$ & n.d. & Various carboxylates and & 22,23 \\
& & carbonates & \\
\hline $1638+1425+1220$ & n.d. & hydrogenocarbonate & 26 \\
\hline
\end{tabular}

9

10

11 A continuum of ill-defined bands was observed between 1750 and $1200 \mathrm{~cm}^{-1}$ after the

12 disappearance of the hydrogenocarbonate bands (Fig. 6, $10 \mathrm{~min}$ ). The most prominent band was

13 located at $1626 \mathrm{~cm}^{-1}$, also exhibiting a shoulder at $1684 \mathrm{~cm}^{-1}$. Bands at these positions can be

14 possibly related to (i) adsorbed molecular water, (ii) carbonates or (iii) multibonded CO.

15 Assigning the rather large 1626 and $1684 \mathrm{~cm}^{-1}$ bands to adsorbed molecular water can be

16 confidently excluded in view of the corresponding very weak signal observed in the region 3800-

$172500 \mathrm{~cm}^{-1}$ (Fig. 6), in contrast to the proportions expected when these bands are due to water O- 
$1 \mathrm{H}$ stretching and H-O-H bending modes, respectively (Fig. 4). A band at $3651 \mathrm{~cm}^{-1}$ was probably

2 due to the perturbation of the missing hydroxyl at $3712 \mathrm{~cm}^{-1}$ by adsorbed species.

3 An additional experiment using ${ }^{13} \mathrm{CO}$ was carried out to confirm that the bands at 1626 and

$4 \quad 1684 \mathrm{~cm}^{-1}$ were not due to water. The spectrum obtained using ${ }^{13} \mathrm{CO}$ led to the expected band

5 redshift of ca. $50 \mathrm{~cm}^{-1}$ for all the bands assigned to carbonyl species (Fig. 7), corresponding to

6 the theoretical wavenumber ratio of ${ }^{12} \mathrm{CO} /{ }^{13} \mathrm{CO}$ of 1.023 within experimental error (Table 1). In

7 particular, the bands at 1626 and $1684 \mathrm{~cm}^{-1}$ were clearly redshifted by the expected value

8 (though the high wavenumber shoulder was not visible in the ${ }^{13} \mathrm{CO}$ spectrum), confirming that

9 these bands were related to an adsorbate containing a $\mathrm{C}-\mathrm{O}$ bond of some order and not to water.

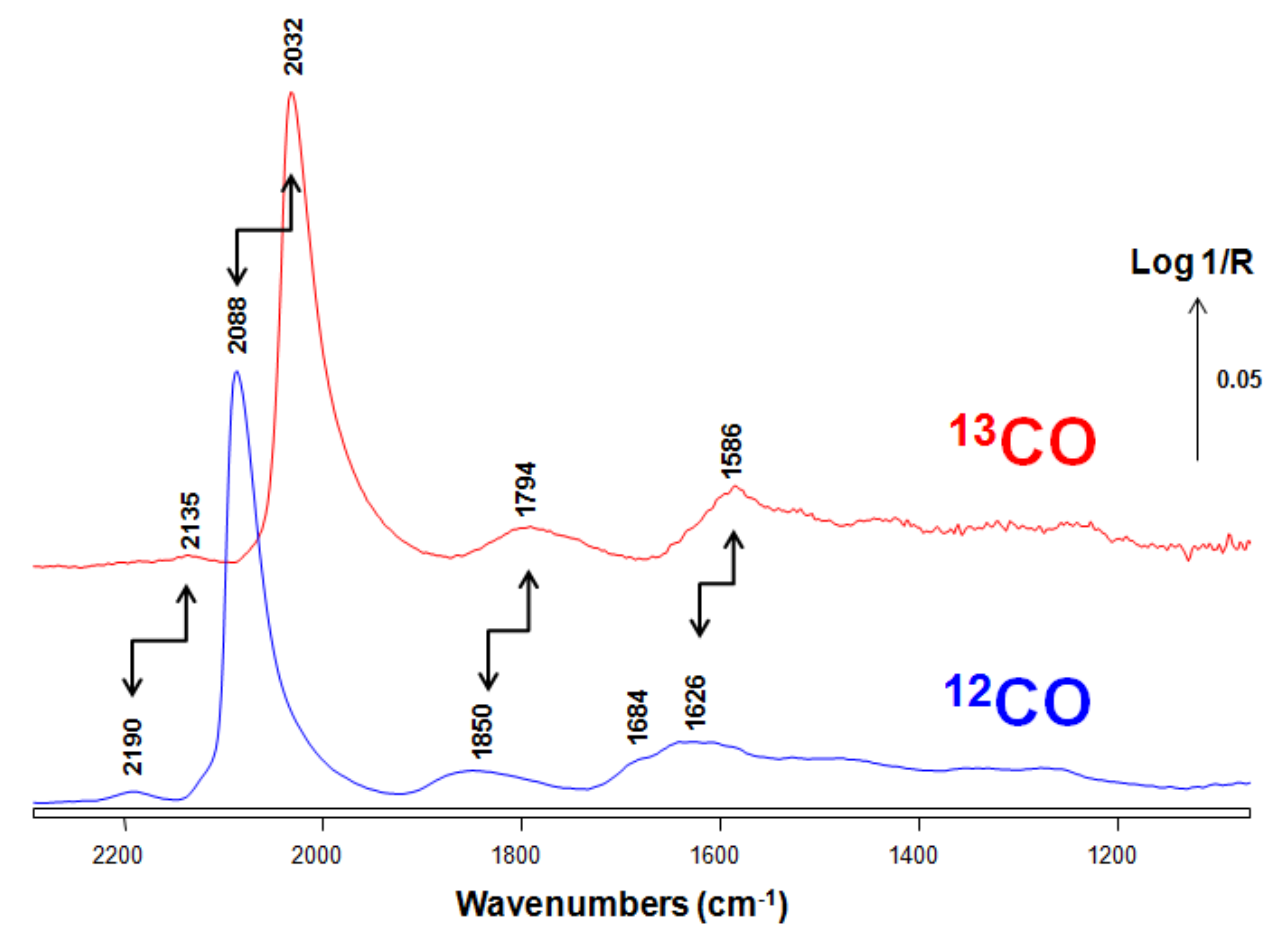

Wavenumbers $\left(\mathrm{cm}^{-1}\right)$

11 Figure 7. DRIFTS spectra collected over the $\mathrm{Pt} / \mathrm{ZrO}_{2}$ at $50^{\circ} \mathrm{C}$ under $3 \% \mathrm{CO} / \mathrm{He}$ at after $10 \mathrm{~min}$

12 following ${ }^{12} \mathrm{CO}$ or ${ }^{13} \mathrm{CO}$ introduction. The spectrum of the sample at the same temperature

13 collected under He before $\mathrm{CO}$ introduction was used as background. The gas-phase spectrum of

14 CO was subtracted. 
2 The evolution of the DRIFTS spectra with time under $\mathrm{CO}$ were monitored using the spectrum 3 collected at $4 \mathrm{~min}$ as reference, since it corresponded to the time at which most oxidized Pt had

4 been reduced and hydrogenocarbonate bands were no longer visible (Fig. 6). The intensity of the

5 broad band centered at $1660 \mathrm{~cm}^{-1}$, which encompassed those at 1626 and $1684 \mathrm{~cm}^{-1}$, clearly 6 decreased (Fig. 8). In contrast, the bands at 2070 and $1841 \mathrm{~cm}^{-1}$, corresponding to linear and 7 bridged $\mathrm{CO}$ adsorbed on $\mathrm{Pt}$, increased.

8

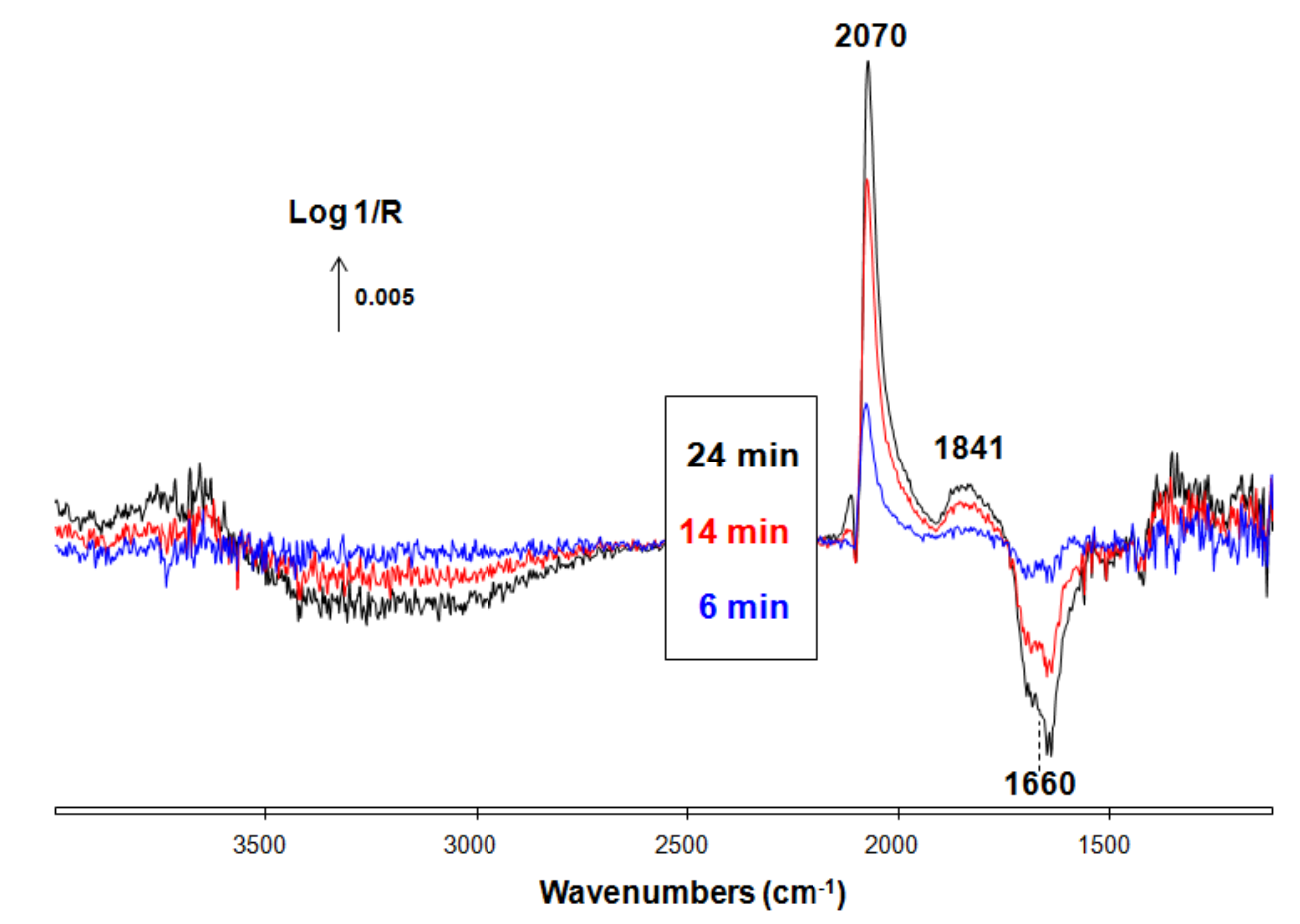

10 Figure 8. Typical DRIFTS spectra collected over the $\mathrm{Pt} / \mathrm{ZrO}_{2}$ at $50^{\circ} \mathrm{C}$ under $3 \% \mathrm{CO} / \mathrm{He}$ at

11 various times following $\mathrm{CO}$ introduction. The spectrum collected after 4 min was used as 12 background. The gas-phase spectrum of $\mathrm{CO}$ was subtracted. 
1 A linear correlation was noted when plotting the area of the linear and bridged bands as a

2 function of the intensity of the $1660 \mathrm{~cm}^{-1}$ band (Fig. 9, Left). This suggests that vanishing species

3 corresponding to the $1660 \mathrm{~cm}^{-1}$ band was quantitatively converted into linear and bridged $\mathrm{CO}$

4 adsorbed on Pt.

5 Similarly, the signal in the $3620-2500 \mathrm{~cm}^{-1}$ region corresponding to hydroxyl stretching

6 vibration modes decayed linearly with respect to the band intensity at $1660 \mathrm{~cm}^{-1}$ (Fig. 9, Right).

7 The slope of the line was far lower than that expected when describing the relation between

8 water bending mode and water hydroxyl stretching modes as described in Fig. 4 and 5.

9 Therefore, the observed decaying signals observed in Fig. 8 were not, in most part, the result of

10 water desorption from the sample.
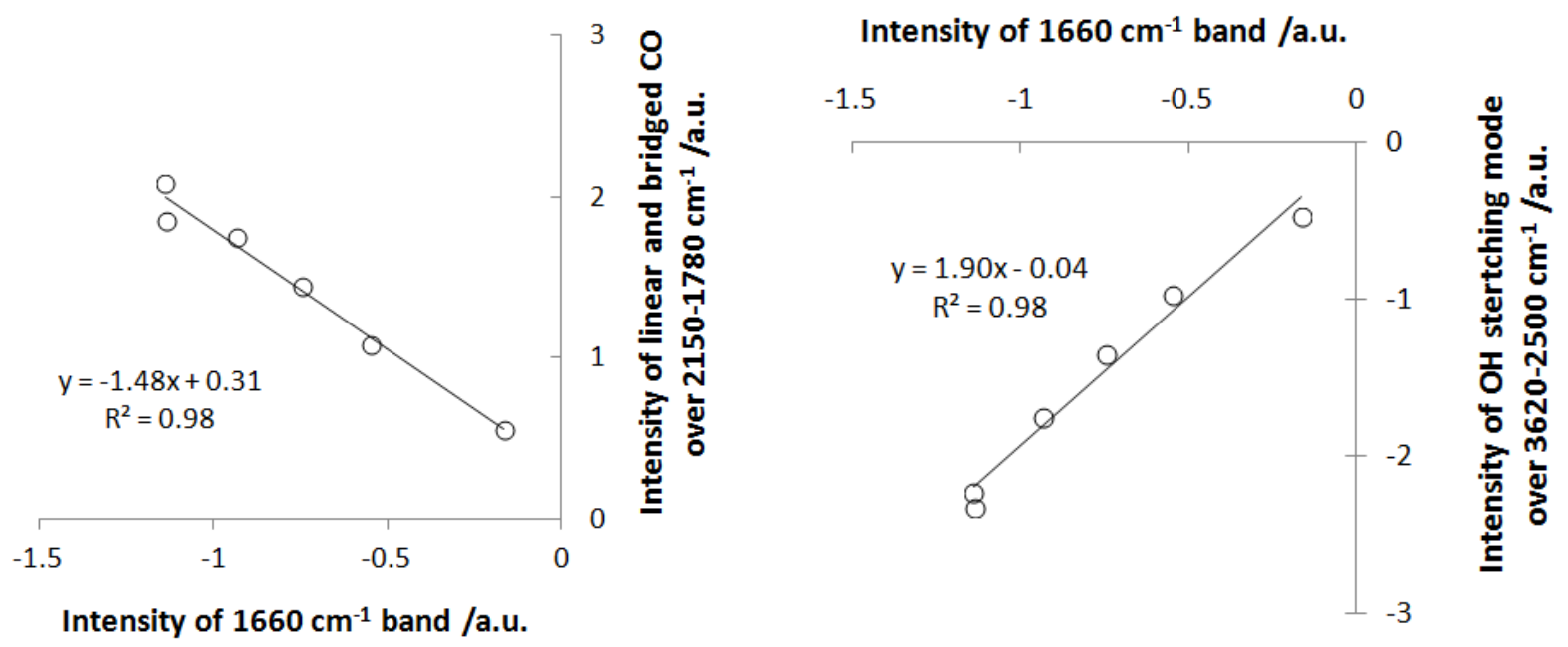

12 Figure 9. Integration of DRIFTS bands relating to the data reported in Fig. 8. (Left) Area of 13 the DRIFTS band of the linear and bridged CO as a function of that of the $1660 \mathrm{~cm}^{-1}$ band. 14 (Right) Area of the DRIFTS band of hydroxyl groups as a function of that of the $1660 \mathrm{~cm}^{-1}$ band. 15 The band at $1660 \mathrm{~cm}^{-1}$ was integrated over the range $1780-1560 \mathrm{~cm}^{-1}$. 
1 A possible explanation for the behavior observed in Fig. 8 and 9 is that the bands around 1660

$2 \mathrm{~cm}^{-1}$ (i.e. ranging from 1684 to $1626 \mathrm{~cm}^{-1}$ in Fig. 6) represented $\mathrm{CO}$ adsorbed on Pt metallic

3 atoms, bridging with a surface hydroxyl group from the support, as represented in Fig. 10. The

4 wavenumber range is consistent with those reported earlier for multibonded $\mathrm{CO}$, notably those

5 involving bonds between the surface and both $\mathrm{C}$ and $\mathrm{O}$ atoms (Fig. 1.A and 1.C and references

6 17,19). In the present case, this adduct is not stable and the bonding between $\mathrm{CO}$ and the surface

7 hydroxyl is gradually lost, possibly due to a rearrangement of the corresponding Pt nanoparticles.

8 New linear and bridging carbonyls are then formed, which do not interact with the support, as

9 suggested by the data reported in Fig. 8.

10 We can reasonably exclude that the bands around $1660 \mathrm{~cm}^{-1}$ were due to some carbonate 11 species, because of the lack of additional bands at lower wavenumbers (Fig. 8), which are 12 expected when the doubly degenerated asymmetric stretching modes of the $\mathrm{D}_{3 \mathrm{~h}}$ carbonate ion at $131415 \mathrm{~cm}^{-1}$ splits upon symmetry $\operatorname{loss}^{22}$.

14 It is therefore possible that single bands observed in other cases in this region may be due to 15 this peculiar bridging carbonyl. The single band at $1670-1690 \mathrm{~cm}^{-1}$ reported by Newton and co16 workers $^{24}$ on alumina-supported $\mathrm{Pt}$, which the authors assigned to a carbonate adsorbed on $\mathrm{Pt}$, 17 may actually be a similar type of carbonyls bridging between Pt and alumina. It must be stressed 18 that the disappearance of this band was also mirrored by the appearance of both bridged and 19 linear $\mathrm{CO}$ adsorbed on Pt (Fig. 3.A in reference 24), exactly as we observed here (Fig. 8).

20 Unfortunately, the $\mathrm{OH}$ stretching region was not shown, so it is not clear whether a change in

21 OH signal also occurred in their case. Resolving the nature of this band is important because it 22 appeared to be the intermediate species leading to $\mathrm{CO}_{2}$ formation during the oxidation of $\mathrm{CO}$ 23 with $\mathrm{O}_{2}$ at room temperature ${ }^{24}$. 
A direct characterization of this species is yet tedious as shown here because of the many other

2 species (water, carbonate, hydrogenocarbonate) that may give rise to IR bands in this region too.

3 This species may actually be the one already reported by Dilara and Vohs ${ }^{17}$, which was assigned

4 to interfacial sites without mentioning the involvement of surface hydroxyl groups. Such sites are

5 potentially important for bifunctional reactions requiring both metal and acid/base properties,

6 particularly those thought to be occurring at the metal - support perimeter. Such adducts formed

7 between Pt and hydroxylated supports could potentially represent crucial reaction intermediates

8 for the CO oxidation and the water-gas shift reaction. . $^{24,42}$

9

10

Figure 10. Schematic representation of a bridging carbonyl bound to $\mathrm{Pt}$ atoms and interacting
12 head-on with the support surface hydroxyl groups, leading to low $\mathrm{C}=\mathrm{O}$ wavenumbers in the

11 Figure 10. Schematic representation of a bridging carbonyl bound to $\mathrm{Pt}$ atoms and interacting
12 head-on with the support surface hydroxyl groups, leading to low $\mathrm{C}=\mathrm{O}$ wavenumbers in the 13 range $1684-1626 \mathrm{~cm}^{-1}$.

14

15

16

17

\section{Conclusions}

7 A zirconia-supported Pt catalyst was shown to exhibit an unusual band around $1660 \mathrm{~cm}^{-1}$ following $\mathrm{CO}$ adsorption that could be confidently assigned to a $\mathrm{Pt}_{2}-\mathrm{CO}$ bridging carbonyl interacting head-on with a surface hydroxyl group of the support. This adduct was yet unstable in the present conditions and was converted into linear and bridged carbonyl only bound to Pt after

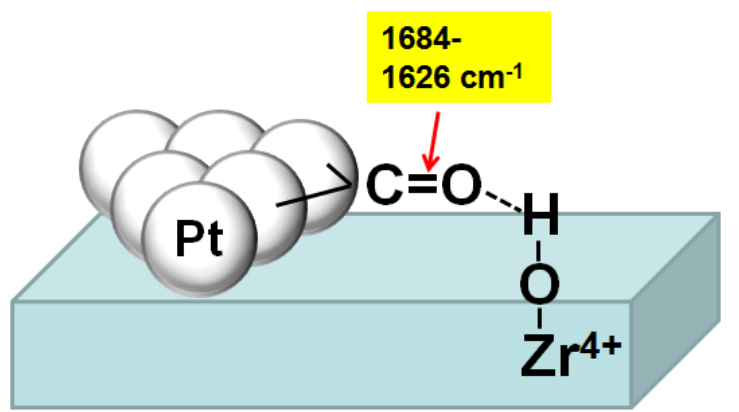


1 a short time. These sites may be of strong catalytic importance in view of the nature of the

2 sorption ensemble (involving atoms at the metal - support interface), but are yet very difficult to

3 investigate because of the many adsorbates (water, carbonates and hydrogenocarbonates) that

4 give rise to bands in the same region.

5

6

7 Corresponding Author

8 * e-mail: fcm@ircelyon.univ-lyon1.fr

\section{Author Contributions}

10 The manuscript was written through contributions of all authors. All authors have given approval

11 to the final version of the manuscript.

\section{Funding Sources}

13 None to be acknowledged.

\section{Notes}

15 The authors declare no competing financial interest.

16

17 ABBREVIATIONS

18 DRIFTS: Diffuse Reflectance Fourier Transform Infra red Spectroscopy.

19 REFERENCES 
1 "Identification of active sites in CO oxidation and water-gas shift over supported Pt catalysts" K. Ding, A. Gulec, A.M. Johnson, N.M. Schweitzer, D. Stucky, L.D. Marks, P.C. Stair,

Science 350 (2015) 189-192.

2 "Catalyst Architecture for Stable Single Atom Dispersion Enables Site-Specific Spectroscopic and Reactivity Measurements of $\mathrm{CO}$ Adsorbed to Pt Atoms, Oxidized Pt Clusters, and Metallic Pt Clusters on TiO2"; L. DeRita, S. Dai, K. Lopez-Zepeda, N. Pham, G.W. Graham, X. Pan, P. Christopher J. Am. Chem. Soc. 139 (2017) 14150-14165.

3 "Isolated Metal Active Site Concentration and Stability Control Catalytic CO2 Reduction Selectivity"; J.C. Matsubu, V.N. Yang, P. Christopher, J. Am. Chem. Soc. 137 (2015) 30763084.

4 "The influence of surface-defects on the IR-spectra of adsorbed species"; P. Hollins, Surf. Sci. Rep. 16 (1992) 51-94.

5 "Pd oxidation under UHV in a model Pd/ceria-zirconia catalyst"; M. Y. Smirnov, G. W. Graham, Catal. Lett. 72 (2001) 39-44.

6 "Characterization of the standard platinum silica catalyst EUROPT 5. Chemisorption of carbonmonoxide and of oxygen"; P. B. Wells, Appl. Catal. 18 (1985) 259-272.

7 "Direct evidence by in situ IR CO monitoring of the formation and the surface segregation of a Pt-Sn alloy"; A. Moscu, Y. Schuurman, L. Veyre, C. Thieuleux, F. Meunier, Chem. Commun. 50 (2014) 8590-8592.

8 "Correlation between $\mathrm{CO}$ frequency and Pt coordination number. A DRIFT study on supported Pt catalysts"; M.J. Kappers, J.H. van der Maas, Catal. Letters 10 (1991) 365-374.

9 "The statistics of surface atoms and surface sites on metal crystals"; R. van Hardeveld and F. Hartog, Surf. Sci., 1969, 15, 189-230.

10 "Effect of preparation technique on the properties of platinum in NaY zeolite: A study by FTIR spectroscopy of adsorbed CO"; K. Chakarova, K. Hadjiivanov, G. Atanasova, K. Tenchev, J. Mol. Catal. A : Chem. 264 (2007) 270-279.

11 "FTIR spectroscopic study of CO adsorption on Pt-H-ZSM-5"; K. Chakarova, M. Mihaylov, K. Hadjiivanov, Micropor. Mesopor. Mater. 81 (2005) 305-312.

12 "Polycarbonyl species in Pt/H-ZSM-5: FTIR spectroscopic study of (CO)-C-12-(CO)-C-13 coadsorption"; K. Chakarova, M. Mihaylov, K. Hadjiivanov, Catal. Commun. 6 (2005) 466-471.

13 "Thermally stable single-atom platinum-on-ceria catalysts via atom trapping"; J. Jones, $\mathrm{H}$. Xiong, A.T. DelaRiva, E.J. Peterson, H. Pham, S.R. Challa, G. Qi, S. Oh, M.H. Wiebenga, X.I.P. Hernandez, Y. Wang, A.K. Datye, Science 353 (2016) 150-154.

14 "Water-Mediated Mars-Van Krevelen Mechanism for CO Oxidation on Ceria-Supported Single-Atom Pt-1 Catalyst"; C. Wang, X.-K. Gu, H. Yan, Y. Lin, J. Li, D. Liu, W.-X. Li, J. Lu, ACS Catalysis 7 (2017) 887-891.

15 "The adsorption of $\mathrm{CO}$ on $\mathrm{Pt}(111)$ studied by infrared reflection-absorption spectroscopy"; B. E. Hayden, A. M. Bradshaw, Surf. Sci. 125, (1983) 787-802.

16 "Probing boundary sites on a Pt/Al2O3 model catalyst by $\mathrm{CO} 2$ hydrogenation and in situ ATRIR spectroscopy of catalytic solid-liquid interfaces"; D. Ferri, T. Burgi, A. Baiker, Phys. Chem. Chem. Phys. 4 (2002) 2667-2672. 
17 "Interaction of $\mathrm{CO}$ with Pt supported on $\mathrm{ZrO} 2(100)$ - Evidence for $\mathrm{CO}$ adsorbed at the PtZrO2 interface"; P.A. Dilara, J.M. Vohs, J. Phys. Chem. 99 (1995) 17259-17264.

18 "Carbonylmetalate-induced phosphorus migration and Ph2PCH2PPh2-(DPPM-)-assisted synthesis of bimetallic complexes and clusters of Pd and Pt with $\mathrm{Mo}, \mathrm{W}, \mathrm{Mn}$, and Co"; P. Braunstein, C. de Méric de Bellefon, B. Oswald, Inorg. Chem. 32 (1993) 1649-1655.

19 "Adduc formation and carbonyl rearrangement of polynuclear carbonyls in presence of group III halides"; J.S. Kristoff, D.F. Shriver, Inorg. Chem. 13 (1974) 499-506.

20 "Infrared spectrometric studies of the surface basicity of metal oxides and zeolites using adsorbed probe molecules"; J.C. Lavalley, Catal. Today 27 (1996) 377-401.

${ }^{21}$ K. Nakamoto, "Infrared and Raman Spectra of Inorganic and Coordination Compounds, Part B: Applications in Coordination, Organometallic, and Bioinorganic Chemistry. Sixth Edition", Wiley Ed., 2009.

22 "Infrared spectroscopic identification of species arising from reactive adsorption of carbon oxides on metal-oxide surfaces"; G. Busca, V. Lorenzelli, Mater. Chem. 7 (1982) 89-126.

23 "Infrared study of CO2 adsorption on hematite"; G. Busca, V. Lorenzelli, Mater. Chem. 5 (1980) 213-224.

24 "Kinetic Studies of the Pt Carbonate-Mediated, Room-Temperature Oxidation of Carbon Monoxide by Oxygen over Pt/AI2O3 Using Combined, Time-Resolved XAFS, DRIFTS, and Mass Spectrometry"; M.A. Newton, D. Ferri, G. Smolentsev, V. Marchionni, M. Nachtegaal, J. Am. Chem. Soc., 138 (2016) 13930-13940.

25 "IR study of polycrystalline ceria properties in oxidised and reduced states"; C. Binet, M. Daturi, J.-C. Lavalley, Catal. Today 50 (1999) 207-225.

26 "Participation of surface bicarbonate, formate and methoxy species in the carbon dioxide methanation catalyzed by ZrO2-supported Ni"; A. Solis-Garcia, J.F. Louvier-Hernandez, A. Almendarez-Camarillo, J.C. Fierro-Gonzalez, Appl. Catal. B : Env. 218 (2017) 611-620.

27 "An investigation of possible mechanisms of the water-gas shift reaction over a ZrO2supported Pt catalyst”; D. Tibiletti, F.C. Meunier, A. Goguet, D. Reid, R. Burch, M. Boaro, M. Vicario, A. Trovarelli, J. Catal. 244 (2006) 183-191.

28 "An in-situ DRIFTS study of the mechanism of the $\mathrm{CO} 2$ reforming of $\mathrm{CH} 4$ over a $\mathrm{Pt} / \mathrm{ZrO} 2$ catalyst"; A.M. O'Connor, F.C. Meunier, J.R.H. Ross, Stud. Surf. Sci. Catal. 119 (1998) 819824.

29 "Selective Aerobic Oxidation of 5-HMF into 2,5-Furandicarboxylic Acid with Pt Catalysts Supported on TiO2- and ZrO2-Based Supports"; H.Ait Rass, N. Essayem, M. Besson, ChemSusChem, 8 (2015) 1206-1217.

30 “"; K. Koichumanova, A.K.K. Vikla, R. Cortese, F. Ferrante, K. Seshan, D. Duca, L. Lefferts, Appl. Catal. B : Env. 232 (2018) 454-463.

31 "Interface effect of mixed phase $\mathrm{Pt} / \mathrm{ZrO} 2$ catalysts for $\mathrm{HCHO}$ oxidation at ambient temperature"; X.Q. Yang, X.L. Yu, M.Y. Lin, M.F. Ge, Y. Zhao, F.Y. Wang, J. Mater. Chem. A, 5 (2017) 13799-13806.

32 "Nanocrystalline ZrO2 and Pt-doped ZrO2 catalysts for low-temperature CO oxidation"; A. Singhania, S.M. Gupta, Beilstein J. Nanotechnol. 8 (2017) 264-271. 
33 "Electrochemical oxidation of ethanol on Pt-ZrO2/C catalyst"; Y.X. Bai, J.J. Wu, J.Y. Xi, J.S. Wang, W.T. Zhu, L.Q. Chen, X.P. Qiu, Electrochem. Commun. 7 (2005) 1087-1090.

34 "Electrocatalytic activity of $\mathrm{Pt}-\mathrm{ZrO} 2$ supported on different carbon materials for methanol oxidation in H2SO4 solution"; R.S. Amin, A.E. Fetohi, R.M.A Hameed, K.M. Khatib, Int. J. Hydrog. Energy 41 (2016) 1846-1858.

35 "Evolution of the catalytic activity in Pt sulfated zirconia catalysts: Structure, composition, and catalytic properties of the catalyst precursor and the calcined catalyst"; J.M. Manoli, C. Potvin, M. Muhler, U. Wild, G. Resofszki, T. Buchholz, Z. Paal, J. Catal., 178 (1998) 338-351.

36 "Hydroisomerisation of $n$-heptane over Pt/sulfated zirconia catalyst at atmospheric pressure"; F.F. Oloye, R. Aliyev, J.A. Anderson, Fuel 222 (2018) 569-573.

37 "A modified commercial DRIFTS cell for kinetically relevant operando studies of heterogeneous catalytic reactions"; F.C Meunier, A. Goguet, S. Shekhtman, D. Rooney, H. Daly, Appl. Catal. A: Gen. 340 (2008) 196-202.

38 "Effective bulk and surface temperatures of the catalyst bed of FT-IR cells used for in situ and operando studies"; H. Li, M. Rivallan, F. Thibault-Starzyk, A. Travert, F.C Meunier, Phys. Chem. Chem. Phys. 15 (2013) 7321-7327.

39 "Quantitative analysis of adsorbate concentrations by diffuse reflectance FT-IR"; J. Sirita, S. Phanichphant, F.C. Meunier, Anal. Chem. 79 (2007) 3912-3918.

40 "An infrared study of sulfated zirconia"; M. Bensitel, O. Saur, J.-C. Lavalley, Mater. Chem. Phys. 19 (1988) 147-156.

41 "A thermogravimetric and FT-IR study of the reduction by $\mathrm{H}-2$ of sulfated $\mathrm{Pt} / \mathrm{CexZr1-xO2}$ solids"; P. Bazin, O. Saur, F.C. Meunier, M. Daturi, J.C. Lavalley, A.M. LeGovic, V. Harle, G. Blanchard, Appl. Catal. B : Env. 90 (2009) 368-379.

42 "CO Oxidation Kinetics over Au/TiO2 and Au/Al2O3 Catalysts: Evidence for a Common Water-Assisted Mechanism"; J. Saavedra, C.J. Pursell, B.D. Chandler, J. Am. Chem. Soc. 140 (2018) 3712-3723. 